\title{
Historical Analysis of Bank Profitability Using CAMEL Parameters: Role of Ownership and Political Regimes in Pakistan
}

\author{
Nadeem Aftab ${ }^{1}$, Nayyer Samad ${ }^{1} \&$ Tehreem Husain $^{2}$ \\ ${ }^{1}$ College of Business Administration, Abu Dhabi University, Al Ain, UAE \\ ${ }^{2}$ Independent Researcher, UAE \\ Correspondence: Nadeem Aftab, College of Business Administration, Abu Dhabi University, 1790, Al Ain, UAE. \\ Tel: 971-3-709-0754. E-mail: nadeem.aftab@adu.ac.ae
}

Received: November 6, 2014

Accepted: December 9, 2014

Online Published: January 25, 2015

doi:10.5539/ijef.v7n2p144

URL: http://dx.doi.org/10.5539/ijef.v7n2p144

\begin{abstract}
In first sixty years of its existence financial sector of Pakistan has experienced two prominent episodes. One, there was an experimentation with the ownership structure of financial institutions which started with promotion of ownership by the private sector and then in 1970s they were nationalized. Subsequently the process was reversed in the 1990s transferring most of the banking assets back to the private sector. Two, on the political front, for long 33 years autocrat have interrupted the democratic order many times. The objective of this study is to take stock of the performance of banking industry when it was in private hands vis-à-vis when banks were nationalized, and, as a supplement, to evaluate the impact of dictatorship versus democracy on the performance of banking industry. Using historical dataset this study offers analysis of banking sector performance by using CAMEL parameters. Our main findings are that when banks are in private hands their profitability is positively related to quality of their assets and management, and it has negative relation with capital adequacy and liquidity. However when banks are under government ownership asset quality and liquidity become irrelevant in determining the profitability whereas capital adequacy, management quality continue to impact bank profitability. This implies that government ownership works like implicit guarantee for banks (a) that they would remain solvent in the short run], and (b) that it would absorb losses emanating from deterioration of bad assets. As regards political regimes the study finds that there is no noticeable difference in the impact of bank specific parameters whether a democratic government is in place or dictatorship is imposed in the country. These findings have implications for bank regulations, monetary policy and for instituting legal reforms in the financial sector.
\end{abstract}

Keywords: banking, CAMEL, democracy, ownership, Pakistan, performance, privatization

\section{Introduction}

For almost three decades, terms like reforms, restructuring, liberalization and privatization have been widely used both in literature and in practice. Economic literature abundantly explores the nexus between finance and growth and the main objective is to find ways for enhancing efficiency in the financial intermediation process. Different countries at different stages of economic development choose a pace and direction of reforms process in their financial systems to advance and sustain their successes and to mitigate effects of the past mistakes. Among others, a major issue under research relates to governments' ownership and control of financial institutions. Calari (2004) made an interesting note that about 40 percent of the world population lives in countries where government is the major owner of the banking system. Essentially the inordinate engagement of the government in the financial sector is justified on grounds that public ownership of banks and Development Financial Institutions (DFIs) serves to boost their role as conduits for channelizing funds to the targeted and underserved sections of the economy.

From a long-term development perspective, it is generally highlighted that the development of those targeted industries or sectors should not be retarded just because the private sector lacks initiative, incentives or capacity. Japan, South Korea, Singapore and lately China are some of the leading examples where the industrialization process has largely been sponsored by state-owned DFIs or those countries have histories of autocratic rules. For countries like Germany, Patel (2004) states that command mode of financial intermediation was used in the postWorld War II era to boost development process of the country. 
Economics literature offers host of studies on the linkage between performance and efficiency indicators and the outcome of reforms and privatization processes however they present mixed results leaving this issue inconclusive. One of the technical reasons projected for absence of certainty about effects of ownership of financial institutions on their performance is heterogeneity of the banks, and others include simultaneity of number of reforms measures initiated during the course of overall restructuring and liberalization of the financial sector. Nonetheless researchers generally agree that when it comes to assessment of bank performance then it is the private entrepreneurship who sets the incentives right, not the government.

Pakistan, a developing country, presents an interesting example of dominant involvement of government, sometimes as a heavyweight owner of financial assets and sometimes asserting itself through the autocratic rule in the country. In short, government has always taken keen interest in the development of the financial sector, inventing ways like credit rationing and fixing credit pricing to channel much needed financial resources to selected sectors of the economy, even until earlier this decade. It is further argued that performance of the financial institutions may be mapped, on almost one-to-one basis, onto the real sector and that is why government directly owns financial institutions or indirectly mandates rules of the game. In this context analyzing performance, efficiency and stability of financial institutions under different ownership regimes presents an intriguing area of research.

Starting from 1974 for almost two decades of government ownership and control rendered banking institutions completely ineffective, operationally as well as financially. Their commercial viability was at stake as most of them had their equity wiped out by bad debts. Every year government had to allocate funds from tax payers' money to sustain institutions which were effectively running down the stream due to: (a) inept human resource allocation; (b) technical inefficiencies; (c) lack of entrepreneurial incentives; (d) collusion of the bank managers and their boards; and (e) dishonest and politically-connected bank borrowers; all examples of distortions in the financial intermediation process resulting in bad lending practices. These factors, taken together, provided the impetus for privatization process. Reform process not only involved change of ownership and control of banks to private hands, but it was also accompanied with overhauling of the supervisory structure at the central bank (risk-based on-site and off-site supervisory structure was introduced in the early part of this decade). Initiatives to reset the financial system of the country kicked in early 1990-1991 and continued through the whole decade. This process involved privatization of state-owned banks, issuance of license to open new private banks, and strengthening and rationalization of branch networks, etc.

Most of the recent studies on banking sector performance in Pakistan use recent data from 1990s onwards and evaluate operational efficiencies using data envelopment analysis. There is hardly any study which takes account of overall financial history of the country. To the best of our knowledge this is the first study which uses parameters from CAMEL framework, the most recent supervisory model, and takes a historical account of banking sector performance from 1953 to 2008. Therefore this research builds on the previous work and fills the gap in economic literature by (a) extending analysis on the overall financial history of Pakistan, and (b) using CAMEL technique to offer unique perspective on the variation in the factors which are relevant to banks' profitability under private ownership versus government control.

The paper has been organized as following. After developing literature review on the subject in Section 2, discussion on data, its sources and structure have been detailed in Section 3. Methodology has been presented in Section 4 which is followed by discussion on empirical findings in Section 5. The last section concludes the paper.

\section{Literature Review, Motivation of the Study, and Hypothesis Development}

\subsection{Literature Review}

The standard theoretical literature presents two popular views on government shareholdings of financial institutions - Development View and Political View (Lewis, 1950, 1955; Gerschenkorn, 1962). The former states that in countries with weak financial institutions, government ownership of strategic institutions, including banks, is needed to jump start both financial and economic development, the foundation of 'commanding heights' approach. In contrast, the Political View takes lead from the principle-agent problem and stipulates that government ownership of financial institutions creates multiple distortions leading to inefficiencies, which is why change in ownership from public to private sector is promoted to enhance efficiency of financial institutions (Kornai, 1979; Shleifer \& Vishny, 1994). Identification of this objective implies that an ideal solution is to completely divest public ownership of assets. Megginson, Nash and Van-Randenborgh (1994) argue that government-owned institutions work at less than the optimal level and their privatization would help control actual or perceived distortions created by their public ownership and control. 
Megginson and Netter (1998) present their theoretical argument that the only possibility that government intervention may be tolerated is when systemic market failure can be avoided by the government actions and this leads us to the idea of government's role as the lender of last resort during crisis times as seen most recently during the Global Financial Crisis (GFC), when ownership of a number of financial institutions was again transferred back to government domain. However, this is considered to be an urgent and temporary measure, focused on mitigating the impact of such an unprecedented crisis (Laven \& Valencia, 2013).

A market-based economic system is inherently incompatible with state involvement in financial business. The general consensus is that privately owned financial institutions are better performers and more efficient than state-owned. While comparing performance, most of the studies find that state-owned, partially privatized, fully privatized or private and foreign banks build an order (from least to the best) of efficiency. For instance, Berger, Hasan, and Klapper (2004) use data of 28 developing countries to show that foreign banks are most efficient, followed by private banks while state-owned banks are least efficient. Boardman and Vining (1989) using four profitability ratios and two measures of X-efficiency find that state-owned and mixed (state and private) ownership enterprises are significantly less profitable and productive than are privately owned firms. They also find that mixed enterprises are no more profitable than State-Owned Enterprises (SOEs), suggesting that full private control, not just partial ownership, is essential to achieving performance improvement. Similar argument has been put forth by empirical research by La Porta, Lopez-de-Silanes and Shleifer (2002).

Focusing on the banking sector, Sathye (2005) has used five years data (1998-2002) on Indian banking industry and tested if the performance of state-owned banks is consistent with privatized or private banks. He applies difference in mean test of significance to confirm if the partially privatized banks perform better and their efficiency indicators exceed those of public banks. He records that partially privatized banks are quickly catching up with fully private banks as there is no significant difference in their performance and efficiency indicators. He argues that gradual off-loading of state-ownership to private sector is an optimal strategy and that it should be accompanied by wider reforms in financial sector.

Various studies have also been conducted to empirically test the relationship between privatization and performance on the domestic banking industry. Using parametric approach, Di Patti and Hardy (2005) have analyzed Pakistani bank data and show that foreign banks are more profit efficient, followed by private and then state-owned banks, but the average cost efficiency of these banks is similar. Another study on the domestic banking system is by Burki and Niazi (2009). They use data envelopment analysis and data from 1991 to 2000 to determine that foreign banks show superior cost efficiency than private and state-owned banks, but that the efficiency of foreign banks deteriorates once the consolidation stage of the financial reforms is over.

In a similar vein Galal, Leroy, Jones and Ingo (1994), Megginson, Nash and Randenborgh (1994), and Megginson Jeffry and Netter (1998) promote the idea of privatization to improve performance of state-owned companies. Boubarki and Cosset (1998) empirically investigated performance of firms in pre- and post-privatization using international data from 21 developing countries including Pakistan, and find that an average representative firm after passing through the privatization process performs better, accumulates reserves and pays dividend regularly. Taking lead from that study, Hakro and Akram (2009), using Pakistani firm level data, have compared the operating and financial performance of pre- and post-privatization periods of firms in almost all sectors of the economy, including banks. Their sample covers 49 out of 161 privatized units during 17 years starting from year 1988. Considering privatization as an event, they have applied test of difference in mean/median values method (by using Wilcoxon signed-rank test) in 3 years before and after privatization sample. However, unlike other studies they found that profitability, efficiency, output and dividends parameters are not significantly different in the two time periods leading them to conclude that the privatization process has not resulted in significant performance enhancement of banks. Main problem in their study is the application of the test of significance on a very small time series, built on limited sample set.

Burki and Ahmad $(2010,2011)$ note that financial sector reforms in Pakistan which started in 1989 graduated subsequently into ridding the banks, the leading financial institutions, of government ownership transferring them to private hands. They highlight that the root cause of this change of ownership was to give private entrepreneurs a chance to turn those inefficient financial bureaucracies into viable commercial financial concerns. Theory of efficient resource allocation through market forces was the main driving force.

Alternate methods of testing potential performance and efficiency enhancements from privatization include 'cost benefit analysis' (for instance used by Galal et al., 1994), ratio analysis, data envelopment analysis (used by Bousoffiane, Martin, \& Parker, 1997), X-efficiency analysis (Qayyum \& Khan, 2007), stochastic frontier analysis (Burki \& Ahmad, 2010), etc. In a most recent study Maththew (2010) has applied DEA on Pakistan 
banking data and finds that in contrast to low technical efficiency enhancements, cost inefficiencies of banking institutions has declined over time. However, the author acknowledges discrepancies in the short-span data set used for analysis and gives mixed conclusions while highlighting limitations of his estimation technique.

\subsection{Motivation of the Study}

The debate on the role of ownership of banks by public versus private owners is rooted in the issue of corporate performance and efficiency enhancement. Public sector ownership of banks, especially in the form of overall nationalization of banking assets, is generally considered counterproductive as it distorts managerial incentives to deliver on their promises. Moreover bank regulation becomes internalized as government assumes role of the owner, ombudsman and the arbiter, etc. Similarly literature on impact of political regimes on the performance of banks and its relation with the ownership is scarce with reference to developing countries. It needs to be explored if the impact of a dictatorial role has any similarities with the nationalization of banking assets or otherwise.

Using almost sixty years of data from banking industry this study attempts to investigate variability in the impact of ownership of banking institutions when it moves from private to public sector. In addition, it explores variation in profitability under different political regimes - democracy versus dictatorship. We hypothesize that profit motive of investors works better under private ownership of financial institutions. It improves quality of assets, advances bank management practices, supports bank liquidity conditions and augments capital adequacy with enhanced profitability.

We assume that when banks are in private hands their profitability increases with improvement in quality of assets and management and falls with accumulation of liquidity and increase in capital. However if government takes over as owner and controller of financial institutions then capital adequacy and management quality continue to affect profitability but asset quality and liquidity drop out of the list of its determinants. In other words dominance of government either as an owner of financial assets or as an autocrat controlling the entire regime eliminates the importance of short term solvency and asset quality as factors affecting performance of the banking institutions. The likely reason for this behavior could be the implicit guarantee provided by the government for short term solvency and viability of financial institutions if asset quality deteriorates. As regards political regimes, our conjecture is that democracy behaves like private ownership of financial institutions and dictatorship has similarities with government ownership of financial institutions.

\subsection{Hypothesis Development}

\subsubsection{Ownership: Private vs. Public}

We hypothesize that under private ownership of financial institutions profitability is linked positively with assets and management quality whereas liquidity and capital adequacy affect profitability negatively. However, when financial assets are in government ownership and control only capital adequacy and quality of bank management continue to affect bank profitability, liquidity and quality of bank assets become irrelevant. A potential explanation may be drawn from government's capacity to become an implicit guarantor of short term solvency and assume the credit risk when asset quality deteriorates.

\subsubsection{Political Regime: Democracy vs. Dictatorship}

As regards political regimes our conjecture is that the bank profitability is affected in the same way by the quality of assets and bank management, liquidity and capital adequacy whether democratic order is maintained in the country or a dictator is ruling it.

These hypotheses have been tested by means of CAMEL framework. Using linear regression model with dummies for private-public ownership and for political regimes, and various ratios to account for asset quality, capital adequacy, liquidity and management performance as independent variables the behavior of Return on Equity (ROE) and Return on Assets (ROA) has been explored. To the best of our knowledge there is no other study which has employed CAMEL parameters on historical data on banking industry in Pakistan. Application of standardized ratios on the aggregate dataset for almost 60 years allows straightforward evaluation of the impact of a variety of factors on the profitability of banking industry.

\section{Data, Methodology and Variables}

\subsection{Data Description}

This study is based on scheduled banks' data from 1953 to 2008. Largely the data for the period 1953-1989 have been taken from various issues of Banking Statistics of Pakistan. an annual publication of the SBP, and supplemented by other sources including various issues of Statistical Bulletin published by State Bank and Handbook of Statistics on Pakistan Economy (2010) and annual audited accounts of the banks wherever they are 
available.

It is important to take a note of different conventions used in constructing variables of interest. For instance while using bank level data two heads of accounts namely 'Head office and interbank adjustments' and 'Contingent assets/liabilities as per contra' have been dropped in calculation of total assets/liabilities position of the consolidated position of the banking sector. The former entries are set off when banks' head offices compile data from all the branches for making annual account, and the latter being same on both assets and liabilities directly drops out. Further, total capital has been defined as sum of paid-up capital, reserves and balance brought forward from last year; earning assets have been defined as sum of advances and investments; total deposits are sum of demand and time deposits; investment includes federal and provincial government securities, shares of local and foreign companies and other investments; and net profit has been calculated by taking difference of total receipts (income) and total disbursements (expenses).

For comparing performance of banking institutions during different ownership regimes period between 1956 and 1973, and 1991 and 2008 together has been taken as private sector ownership and that between 19741990 as a period of public ownership of banking assets. As a supplemental work the period from 1953 to 2008 has been divided into democratic and autocratic rules. The former presents the time in which elected governments are in place (1953 to 1958,1971 to 1977 , and 1989 to 1999 ) and the later represents dictatorial rules (1958 to 1969 , 1977 to 1988 , and 1999 to 2008 ).

\subsection{Methodology}

Using unique aggregated bank level data set covering 60 years of financial history of the country, we have employed CAMEL parameters to measure effect of different bank specific factors on the profitability of banks in Pakistan. Our model takes following form:

$$
\text { Earnings }_{t}=\alpha_{0}+\beta_{i} X_{t}+\gamma_{i} C_{t}+\varepsilon_{t}
$$

Where Earnings, used as a dependent variable, measures profitability of banks alternatively first as a ratio of net profit to total equity (Return on Equity, ROE) and as a ratio of net profit to total assets (Return on Assets, ROA). On the right-hand side of the equation $\mathrm{Xt}$ is a vector of explanatory variables and $\beta$ is are their respective coefficients. The vector Xt includes popular determinants of profitability of banks such as total capital to total assets ratio - a measure of capital adequacy, growth rate of assets - a measure of asset quality of banks, total expenditures to total income ratio - a measure of managements' performance, and finally total deposits to total advances ratio - a measure of bank liquidity. The vector $\mathrm{Ct}$ of control variables include growth rate of real Gross Domestic Product (GDP), growth rate of money supply (M2), and growth rate of branch network of banks. These variables generally control for the effects of macro-monetary shocks. The last item in equation (1) is $\varepsilon_{t}$ represents white-noise error term.

Following models present the functional forms in which dummy variables have been deployed to judge the impact of (a) ownership (private versus public) on banks profitability, and (b) political regime (democracy versus autocratic rule) on banks profitability.

$$
\begin{gathered}
\text { Earnings }_{t}=\alpha_{0}+\beta_{i} X_{t}+\gamma_{i} C_{t}+\text { Ownership }_{i}+\varepsilon_{t} \\
\text { Earnings }_{t}=\alpha_{0}+\beta_{i} X_{t}+\gamma_{i} C_{t}+\text { Political Regime }_{i}+\varepsilon_{t}
\end{gathered}
$$

\subsection{Description of Variables}

\subsubsection{Bank Profitability}

Earnings, which add strength to banks' capital base and ensure viability of banking institutions in the long run, may be gauged by return on equity (RoE) and return on assets (RoA). Data series shows that during the period 1956-1973 when banking assets were in private hands, profitability of banks declined from 1.3 in 1956 to 0.8 in 1973. Similar pattern was observed during the nationalization period where profitability was healthy in the beginning and then started declining with a small uptick during 1983-1984. Thereafter, during 1990s and 2000s, the period of financial reforms, profitability improved after privatization of MCB and ABL in 1991. However it declined only later with erosion of earning assets and amassing of nonperforming assets of HBL and UBL dipping to the losses during 1997-1998. Moreover, freezing of foreign currency accounts in 1998 also had its detrimental impact on the profitability of foreign banks operating in Pakistan. However in 2000s bank profitability improved significantly along with handing over of HBL and UBL to the private sector.

\subsubsection{Capital Adequacy}

Total capital to total assets ratio, a measure of capital adequacy, shows the capacity of financial institutions to absorb losses after all other options of risk absorption have been exhausted. During 1958-1963 this ratio 
improved and as the banks expanded their business, this ratio declined and except for the years 1969-1970, it continued on its downtrend, touching the 1.8 percent mark in 1976. Afterwards it started rising crossing 5 percent mark in 1988. During the nationalization period blanket guarantee was issued by the government to the deposit holders of all the nationalized banks. That was a time when capital was linked to deposits and sovereign guarantee to depositors did not motivate the banks to expand their capital base. In 1981 the paid-up capital of most of the nationalized banks was increased simultaneously indicating that the decision to expand the capital was more administrative in nature than based upon technical reasons. Later on during the period of reforms and privatization, banks' capital base improved considerably. In fact the process of reforms and restructuring forced mergers and acquisitions of many small and fragile banks thereby increasing their fallback cushion; and two, implementation of Basel Capital Accord compelled banks to expand their total capital according to the level and nature of risks they are exposed to.

\subsubsection{Asset Quality}

Asset quality of banks can be gauged by the growth rate of total assets and data shows that it deteriorated during the nationalization period. Growth rate of advances picked up with the growth in overall economic activity in 1959. This period setting foundation of financial liberalization witnessed marked growth in advances. For the year 1965 when Indo-Pak war broke out growth in advances declined. In 1966 introduction of concessionary lending scheme for small loans have had its beneficial effect on growth in advances modestly pulling it up. Later on, in 1968 credit ceilings as a credit control tool were introduced which had its detrimental impact on growth of advances in 1969. Another factor which affected growth of advances was the change in interest rate on advances charged by bigger banks which was increased from 8 percent to 9 percent and later on maximum interest rate charged by smaller banks was also increased from 10 to 11 percent in 1972 .

\subsubsection{Management}

Like any other service industry, financial sector's performance is heavily dependent upon the health and soundness of its management. It is the most difficult aspect to objectively quantify across firms in the same industry as well as over time. Two variables are popularly used to gauge management soundness of banks; total expenditures to total income ratio and earnings per employee. In this study we have relied on 'profit per employee' as a measure of management performance. In the earlier part of the pre-nationalization period it was very low on account of linear expansion of the industry. However, when government started granting licenses to new private banks it went up very quickly. Part of the explanation of comes from unhealthy competition among banks, and rest is a story of massive corruption and inefficiencies in the banking practices of that time. However average ratio of this period was more than 10 marks lower than the average of nationalization period. A closer look at the table shows that soon after nationalization this ratio came down from 88.4 percent in 1973 to 86.0 percent in first two years of the nationalization period. Starting from 1976 it started rising and touched the peak in 1985 and slid down little bit afterwards and rose again in 1990.

\subsubsection{Liquidity}

Although collecting deposits and extending loans is considered to be the main activity of deposit money institutions, however a high advances to deposit (ADR) ratio indicates liquidity strain which has the potential to damage the overall performance of banks. Comparison of pre- and post-nationalization period with government owned and controlled era of 1974-1990 shows that the ratio was high during the nationalization period when schemes of directed credit were introduced and nationalized banks did heavy funding of public sector enterprises. A cursory look at the pre-nationalization period shows that this ratio remained above the 80 percent mark during 1964 to 1970, a period when private sector banks mushroomed. Industry and connected lending practices siphoning depositors' money to related parties of the banking institutions were pervasive during the period. In the current post-public sector dominance period, this ratio has become stable and stayed around a yearly average of 67.6 percent.

\section{Results}

This section presents regression results of the impact of bank specific factors on bank profitability after controlling for macroeconomic variables and the size of the banking industry.

\subsection{Descriptive Analysis}

Table 1 gives summary statistics on selected variables. Both the dependent and main independent variables are ratios of different factors as explained in other sections, and control variables are in percent growth form. As the data shows most of the variables are asymmetrical (three negatively and rest positively skewed). Over a period of 56 years mean return on equity is 28 percent whereas mean return on assets is only 1 percent. Asset quality 
which has been measured as growth of assets has a 16 percent with a standard deviation of 8 percent. Liquidity, measured by ratio of advances to deposits, has a mean of 71 percent ad standard deviation of 10 percent. Profit per employee, a measure of management quality of the overall banking industry, has a mean of 10 percent with a standard deviation of 23 percent. This shows wide variability in the size of the banks, some a small and others are very large. Average amount of capital to total assets ratio is close to 2 percent with a standard deviation of 1 percent. Since risk-weighting of assets is a modern concept and has been in practice for last 10 to 15 years or so, therefore total assets have been used in the denominator and that explains the smaller size of capital adequacy measure.

Table 1. Summary statistics of selected variables

\begin{tabular}{lllllll}
\hline Variable & Mean & Std. Dev. & Min. & Max. & Skewness & Kurtosis \\
\hline Return on Equity & 0.28 & 0.14 & -0.18 & 0.68 & 0.03 & 2.9 \\
Return on Assets & 0.01 & 0 & 0 & 0.02 & -0.36 & 6.31 \\
Asset Quality & 0.72 & 0.07 & 0.57 & 0.86 & -0.25 & 1.97 \\
Liquidity & 0.71 & 0.1 & 0.43 & 0.87 & -0.7 & 3.05 \\
Profit per Employee & 0.1 & 0.23 & -0.1 & 0.98 & 2.67 & 2.12 \\
Capital Adequacy & 0.02 & 0.01 & 0.01 & 0.05 & 0.63 & 3.03 \\
M2 Growth & 13 & 6 & 0 & 29 & 0.3 & 2.92 \\
Branch Growth & 7 & 12 & -24 & 36 & 0.6 & 3.67 \\
Real GDP Growth & 5.28 & 2.32 & 0.9 & 10.2 & 0.03 & 2.2 \\
Assets Growth & 16 & 8 & 2 & 35 & 0.32 & 2.95 \\
\hline
\end{tabular}

From the pool of control variables, money supply, an indicator of monetary expansion in the country, grew at an average rate of 13 percent with a standard deviation of 6 percent, branch network of the banks, a proxy for overall expansion in banking business, expanded by 7 percent with a standard deviation of 12 percent, and GDP (at constant factor cost), a measure of overall economic growth of the economy, grew on average by 5.28 percent with a standard deviation of 2.32 percent.

\subsection{Regression Analysis}

This section discusses regression estimates of alternate specifications. Basic model covers all the years and ROE has been used as a dependent variable to explore the impact of asset quality, bank liquidity, capital adequacy and management quality of banks. In all the models growth rates of broad measure of money supply (M2) and gross domestic product (GDP) along with size of banking industry branch network have been used as controls.

Table 2. Impact of ownership and bank specific parameters on profitability (dependent variable: ROE)

\begin{tabular}{|c|c|c|c|}
\hline Variables & Model 1: Overall & Model 2: $\mathrm{D}_{\text {own }}=1$ & Model 3: $\mathrm{D}_{\mathrm{own}}=\mathbf{0}$ \\
\hline \multirow{2}{*}{ Total Assets Growth } & 0.299 & 0.481 & -0.066 \\
\hline & -1.35 & $(2.02)^{* *}$ & -0.35 \\
\hline \multirow[t]{2}{*}{ Liquidity } & 0.001 & -0.287 & 0.084 \\
\hline & -0.01 & $(1.75)^{*}$ & -0.24 \\
\hline \multirow[t]{2}{*}{ Capital Adequacy } & -8.852 & -5.896 & -11.697 \\
\hline & $(5.91)^{* * *}$ & $(3.40)^{* * *}$ & $(2.90)^{* * *}$ \\
\hline \multirow[t]{2}{*}{ Management Quality } & 0.442 & 0.394 & 1.947 \\
\hline & $(5.02)^{* * *}$ & $(4.16)^{* * *}$ & -0.61 \\
\hline \multirow[t]{2}{*}{ M2 Growth } & -0.12 & $-0.571^{*}$ & 0.166 \\
\hline & -0.41 & $(1.79)^{*}$ & -0.4 \\
\hline \multirow[t]{2}{*}{ GDP Growth } & -0.004 & 0.004 & $-0.020 * *$ \\
\hline & -0.52 & -0.46 & $(2.08)^{* *}$ \\
\hline \multirow[t]{2}{*}{ Branch Growth } & 0.443 & 0.357 & 0.592 \\
\hline & $(3.15)^{* * *}$ & $(2.22)^{* *}$ & $(3.19)^{* * *}$ \\
\hline \multirow[t]{2}{*}{ Constant } & 0.55 & 0.59 & 0.721 \\
\hline & $(4.69)^{* * *}$ & $(5.11)^{* * *}$ & $(2.05)^{* *}$ \\
\hline F-Statistics & 8.06 & 4.34 & 29.22 \\
\hline R-Squared & 0.54 & 0.5 & 0.96 \\
\hline Adj R-Squared & 0.47 & 0.38 & 0.93 \\
\hline
\end{tabular}


Table 2 shows regression results in three different settings. First model (Overall) uses all observation in the dataset and tests dependence of ROE on the above stated variables. It shows that growth of assets, liquidity and better management quality have positive influence on the bank profitability however impact of only management quality is statically significant. Unlike Athanasoglou, Brissimis and Delis (2005), and Jha and Hui,(2012) who find a positive relation between capital and bank profitability, our results show that capital adequacy has a significant negative impact on profitability. A potential explanation is that it is costly for the banks to increase capital and it dampens their profitability. Model 2 and 3 use dummy for ownership variable. Regression estimates show that when banking assets are owned by private investors (ownership dummy, $\mathrm{D}_{\text {own }}=1$ ) both asset and management quality affect bank profitability positively whereas liquidity and capital adequacy have negative effect on bank profitability. These findings are consistent with Bourke (1989) who studied impact of internal factors on bank profitability. All these coefficients are statistically significant. These findings support the argument that private ownership of financial resources is better than the alternate of transferring them into public domain because the former has the right set of incentives to innovate and contain overall cost (Shleifer, 1998).

On the other hand, when banking assets are owned by the government (ownership dummy, $\mathrm{D}_{\text {own }}=0$ ) only capital adequacy is the relevant determinant; other variables change their direction of relation with the ROE however they are statistically insignificant showing that they have no influence in determining bank profitability. This indicates the inability of government as an owner to discipline the banks and the potential role of implicit guarantee of the state to keep the banks afloat under its ownership. While studying impact of state-ownership on bank loans, Jiang and Zeng (2014) present similar argument on the weak ability of government to discipline the banks. Taking lead from lazy banking hypothesis (Manove, Padilla, \& Pagano, 2001; Emran \& Farazi, 2009) one can argue that under government ownership banks' incentive to evaluate projects becomes weak and they start investing heavily in risk-free government securities to create a cushion for generating cash anytime thereby delinking liquidity from profitability of the banks.

To check for robustness of the results, alternate measure of profitability, ROA, has been regressed on set of parameters as above and, on the whole, the findings are consistent with the outcomes of ROE as a dependent variable. Regression estimates with ROA are presented in Appendix Table A1.

Table 3. Impact of political regimes and bank specific parameters on profitability (dependent variable: ROE)

\begin{tabular}{|c|c|c|c|}
\hline & & & \\
\hline Variables & Model 1: Overall & Model 2: $\mathrm{D}_{\text {Rule }}=1$ & Model 3: $D_{\text {Rule }}=0$ \\
\hline \multirow[t]{2}{*}{ Growth Assets } & 0.299 & 0.254 & 0.064 \\
\hline & -1.35 & -0.66 & -0.27 \\
\hline \multirow[t]{2}{*}{ Liquidity } & 0.001 & -0.011 & -0.329 \\
\hline & -0.01 & $(2.05)^{* *}$ & -1.25 \\
\hline \multirow[t]{2}{*}{ Capital Adequacy } & -8.852 & -2.032 & -4.024 \\
\hline & $(5.91)^{* * *}$ & $(5.44)^{* * *}$ & $(-2.63)^{* * *}$ \\
\hline \multirow[t]{2}{*}{ Management Quality } & 0.442 & 2.25 & 0.224 \\
\hline & $(5.02)^{* * *}$ & $(4.02)^{* * *}$ & $(2.77)^{* * *}$ \\
\hline \multirow[t]{2}{*}{ Growth M2 } & -0.12 & -0.027 & 0.359 \\
\hline & -0.41 & -0.07 & -0.84 \\
\hline \multirow[t]{2}{*}{ Growth GDP } & -0.004 & -0.011 & 0.007 \\
\hline & -0.52 & -0.98 & -0.99 \\
\hline \multirow[t]{2}{*}{ Growth Branch } & 0.443 & 0.308 & 0.269 \\
\hline & $(3.15)^{* * *}$ & $(1.98)^{* *}$ & $(1.88)^{*}$ \\
\hline \multirow[t]{2}{*}{ Constant } & 0.55 & 0.918 & 0.53 \\
\hline & $(4.69)^{* * *}$ & $(4.69)^{* * *}$ & $(3.87)^{* * *}$ \\
\hline F-Statistics & 8.06 & 9.82 & 4.73 \\
\hline R-Squared & 0.54 & 0.81 & 0.58 \\
\hline Adj R-Squared & 0.47 & 0.73 & 0.46 \\
\hline
\end{tabular}

Note. ${ }^{* * *} \mathrm{p}<0.01,{ }^{* *} \mathrm{p}<0.05,{ }^{*} \mathrm{p}<0.1$, Values in parenthesis are t-values.

From Table 3, the first column (Model 1: Overall) gives regression estimates without the use of dummy variable. Column 2 (Model 2: DRule =1) presents results of regression estimate when dummy variable is set to account for years when country was under democratic dispensation. The last column (Model 3: DRule $=0$ ) accounts for those years when country was witnessing autocratic rule. Model 2 shows that when a democratic order is 
maintained in the country the quality of banking assets and that of their management exert positive significant impact on the profitability of the banking industry however liquidity and capital adequacy affect profitability negatively. On the other hand, Model 3 shows that when country is ruled by dictatorship regression coefficients for asset quality and liquidity become statistically insignificant whereas capital adequacy and quality of management continue to have significant negative and positive impact respectively. A probable explanation is that under autocratic rule short solvency is guaranteed by the government just like under government ownership of the banking institutions. These results show that a dictatorial regime behaves more like an implicit government guarantee for short term solvency of the banking institutions and also provide blanket coverage for any deterioration in the quality of assets. However, like in other models, an increase in bank capital imposes a cost and depresses the profitability and a better management gives a boost to it. Consistent with Przeworski and Limongi (1993) who argue that thinking in terms of regimes does not seem to capture the differences in economic growth; our findings also do not find any difference in the impact of change in political regime between democracy and dictatorship on the bank profitability.

Table A2 in Appendix shows results for impact of change in political regime on the behavior of banks specific parameters interacting with bank profitability. Here, ROA, an alternate measure of profitability has been regressed on set of parameters, and on the whole, the findings are consistent with the outcomes of ROE as a dependent variable.

\section{Conclusion}

In this study we have tried to explore the impact of change in ownership and political regimes on bank performance by deploying parameters of CAMEL framework. Dummies for private-public ownership and for political regimes, along with a time series of asset quality, capital adequacy, liquidity and management performance have been regressed on return on equity, and then return on assets, as measures of bank profitability. This approach allows straightforward evaluation of the impact of these factors on profitability of banking industry by using historical data. Unlike other studies on the subject privatization and its impact on performance of banking institutions, our focus is to capture the variation in the behavior of different bank specific variables on the bank profitability when they are tested in competing ownership models (private versus government) and political orders (democracy versus dictatorship). The study estimates bank profitability by innovatively using parameters from CAMEL framework, a standardized bank supervisory model, and makes use of historical dataset on the banking industry of Pakistan.

The findings highlight interesting features related to profitability of banking industry. After controlling for effects of real GDP growth, growth of money supply (M2) and growth of bank branches (as a proxy for size of the banking industry), the base model shows that main determinants of bank profitability (measured by ROE and ROA) are quality of banking assets and that of its management, bank liquidity and its capital adequacy. Our main findings are that with the quality of its assets and management bank profitability has positive relation and with liquidity and capital adequacy it has negative relation. In the next stage then dummy variables are used to estimate impact of (a) change in bank ownership from private to public domains, and (b) impact of change in political regime from democracy to dictatorship.

Regression estimates show that when banking institutions are in private control bank profitability increases with improvement in quality of assets and management, and it goes down when banks increase capital base or hoard liquidity. These findings are consistent with the profit-motive of the investors when banking assets are in private hands. However when banks are owned by the government, the linkage between quality of assets and liquidity becomes statistically insignificant implying that government becomes a guarantor of short term solvency and provides cover for asset deterioration.

Using similar set of parameters, the study finds that the behavior of the bank specific independent variables (capital adequacy, asset quality, management quality and bank liquidity) do not change whether democracy is the mode of governance or it is under autocratic rule.

The paper has lessons for countries who have experienced nationalization of banking assets and for those who have witnessed alternating democratic and dictatorial rules. It suggests that government ownership or shift in political orders may limit the dividends from the efficiency induced by the incentive for private investors especially those residing in democracies.

\section{References}

Ahmed, G., Leroy, J., Tandon, P., \& Vogelsang, I. (1994). Welfare Consequences of Selling Public Enterprises. New York: Oxford University Press. 
Athanasoglou, P., Brissimis, S., \& Delis, M. (2005). Bank-specific, Industry-specific and Macroeconomic Determinants of Bank Profitability. Bank of Greece Working Paper 25. Retrieved from http://mpra.ub.uni-muenchen.de/32026/

Berger, A. N., Hasan, I., \& Klapper, L. F. (2004). Further Evidence on The Link Between Finance and Growth: An International Analysis of Community Banking and Economic Performance. Journal of Financial Services Research, 25, 169-202. http://dx.doi.org/10.1023/B:FINA.0000020659.33510.b7

Boardman, A. E., \& Vining, A. R. (1989). Ownership and Performance in Competitive Environments: A Comparison of The Performance Of Private, Mixed, and State-Owned Enterprises. Journal of Law and Economics, 32(1), 1-33. http://dx.doi.org/10.1086/467167

Boubakri, N., \& Cosset, J. (1998). The Financial and Operating Performance of Newly Privatized Firms: Evidence from Developing Countries. The Journal of Finance, 53, 1081-1110. http://dx.doi.org/10.1111/0022-1082.00044

Bourke, P. (1989). Concentration and other determinants of bank profitability in Europe, North America and Australia. Journal of Banking and Finance, 13, 65-79. http://dx.doi.org/10.1016/0378-4266(89)90020-4

Boussofiane, A., Martin, S., \& Parker, D. (1997). The Impact on Technical Efficiency of The UK Privatization Programme. Applied Economics, 29(3), 98-118. http://dx.doi.org/10.1080/000368497327074

Burki, A. A., \& Ahmad, S. (2010). Bank Governance Changes in Pakistan: Is There A Performance Effect? Journal of Economics and Business, 62(2), 129-146. http://dx.doi.org/10.1016/j.jeconbus.2009.08.002

Burki, A. A., \& Ahmad, S. (2011). The Impact of Bank Governance on Bank Performance in Pakistan. The Lahore Journal of Economics, 16(SE), 271-300.

Burki, A. A., \& Niazi, G. S. K. (2010). Impact of Financial Reforms on Efficiency of State-Owned, Private and Foreign Banks in Pakistan. Applied Economics, 42, 3147-3160. http://dx.doi.org/10.1080/00036840802112315

Calari, C. (2004). The Role of State-owned Financial Institutions: Policy and Practice. 8th Global Conference on Business \& Economics.

Di Patti, E. B., \& Hardy, D. C. (2005). Financial Sector Liberalization, Bank Privatization, and Efficiency: Evidence from Pakistan. Journal of Banking \& Finance, 29(8-9), 2381-2406. http://dx.doi.org/10.1016/j.jbankfin.2005.03.019

Emran, M. S., \& Farazi, S. (2009). Lazy Banks? Government Borrowing and Private Credit in Developing Countries. Retrieved from http://papers.ssrn.com/sol3/papers.cfm?abstract_id=1418145

Galal, A., Leroy, J., Pankaj, T., \& Ingo, V. (1994). Welfare Consequences of Selling Public Enterprises: An Empirical Analysis: A Summary. New York: Oxford University Press. http://dx.doi.org/10.1596/0-8213-2976-6

Gerschenkron, A. (1962). Economic Backwardness in Historical Perspective. Cambridge, MA, Harvard University Press.

Hakro, N. A., \& Akram, M. (2009). (Pre-Post) Performance Assessment of Privatization Process in Pakistan. International Review of Business Research Papers, 5(1), 70-86.

Hardy, D. C., \& Di Patti, E. B. (2005). Financial sector liberalization, bank privatization, and efficiency: Evidence from Pakistan. Journal of Banking \& Finance, 29(8-9), 2381-2406. http://dx.doi.org/10.1016/j.jbankfin.2005.03.019

Jha, S., \& Hui, X. (2012). A Comparison of Financial Performance of Commercial Banks: A Case Study of Nepal. African Journal of Business Management, 6(25), 7601-7611.

Jiang, W., \& Zeng, Y. (2014). State ownership, bank loans and corporate investment. International Review of Economics \& Finance, 32, 92-116. http://dx.doi.org/10.1016/j.iref.2014.01.009

Kornai, J. (1979). Resource-constrained vs. Demand-constrained Systems. Econometrica, 47, 801-819. http://dx.doi.org/10.2307/1914132

La Porta, R., Lopez-De-Silanes, F., \& Shleifer, A. (2002). Government Ownership of Banks. The Journal of Finance, 57, 265-301. http://dx.doi.org/10.1111/1540-6261.00422

Laven, L., \& Valencia, F. (2013). Systemic Banking Crisis Database. IMF Economic Review, 61, $225-270$. http://dx.doi.org/10.1057/imfer.2013.12 
Lewis, W. A. (1950). The Principles of Economic Planning. London: G. Allen \& Unwin.

Lewis, W. A. (1955). The Theory of Economic Growth. London: G. Allen \& Unwin.

Lopez-De-Silanes, F., Shleifer, \& Vishny, R. W. (1997). Legal Determinants of External Finance. The Journal of Finance, 52, 1131-1150. http://dx.doi.org/10.1111/j.1540-6261.1997.tb02727.x

Manove, M., Padilla, A. J., \& Pagano, M. (2001). Collateral versus Project Screening: A Model of Lazy Banks. Rand Journal of Economics, 32(4), 726-744. http://dx.doi.org/10.2307/2696390

Matthews, K. (2010). Banking Efficiency in Emerging Market Economies. Paper presented on Zahid Husian Memorial Lecture Series No. 17, 2010, State Bank of Pakistan, Karachi.

Megginson, W. L. (2004). The Economics of Bank Privatization. SSRN Working Paper No. 492425. Retrieved from http://papers.ssrn.com/sol3/papers.cfm?abstract_id=492425

Megginson, W. L., \& Netter, J. M. (1998). From State to Market: A Survey of Empirical Studies on Privatization. Working Paper, New York Stock Exchange and SBF Bourse de Paris.

Megginson, W. L., Nash, R. C., \& Van Randenborgh, M. (1994). The Financial and Operating Performance of Newly Privatized Firms: An International Empirical Analysis. Journal of Finance, 49, 403-452. http://dx.doi.org/10.1111/j.1540-6261.1994.tb05147.x

Patel, U. (2004). Role of State-Owned Financial Institutions in India: Should the Government Do or Lead? Paper presented at the World Bank, IMF and Brookings Institution Conference on Role of State-Owned Financial Institutions, Washington D.C., April 26-27. 2004.

Przeworski, A., \& Limongi, F. (1993). Political Regimes and Economic Growth. Journal of Economic Perspectives, 7(3), 51-69. http://dx.doi.org/10.1257/jep.7.3.51

Qayyum, A., \& Khan, S. (2007). X-efficiency, Scale Economies, Technological Progress and Competition: A Case of Banking Sector in Pakistan. Pakistan Institute of Development Economics Working Paper No. 2007:23.

Sathye, M. (2005). Technical Efficiency of Large Bank Production in Asia and the Pacific. Multinational Finance Journal, 9(1/2), 1-22.

Shleifer, A., \& Vishny, R. (1994). Politicians and Firms. Quarterly Journal of Economics, 109, 995-1025. http://dx.doi.org/10.2307/2118354

Shleifer, A. (1998). State versus Private Ownership. Journal of Economic Perspectives, 12(4), $133-150$. http://dx.doi.org/10.1257/jep.12.4.133

\section{Appendix A}

Table A1. Impact of ownership and bank specific parameters on ROA

\begin{tabular}{llll}
\hline Variables & Model 1: Overall & Model 2: $\mathrm{D}_{\text {own }}=\mathbf{1}$ & Model 3: $\mathrm{D}_{\text {own }}=\mathbf{0}$ \\
\hline Total Assets Growth & 0.008 & 0.013 & -0.003 \\
& $(1.71)^{*}$ & $(2.05)^{* *}$ & -0.77 \\
Liquidity & -0.004 & -0.009 & 0.001 \\
& -1.13 & $(2.06)^{* *}$ & -0.18 \\
Capital Adequacy & -0.074 & -0.069 & -0.051 \\
Management Quality & $(2.21)^{* *}$ & -1.62 & -0.73 \\
& 0.013 & 0.014 & -0.003 \\
M2 Growth & $(6.30)^{* * *}$ & $(5.69)^{* * *}$ & -0.06 \\
& -0.008 & -0.016 & -0.001 \\
GDP Growth & -1.2 & $(1.93)^{* *}$ & -0.07 \\
& 0 & 0 & 0 \\
Branch Growth & -0.41 & -0.36 & $(2.46)^{* *}$ \\
& 0.009 & 0.012 & 0.004 \\
Constant & $(2.98)^{* * *}$ & $(2.93)^{* * *}$ & -1.25 \\
& 0.011 & 0.013 & -0.01 \\
F-Statistics & $(4.02)^{* * *}$ & $(2.305)^{* * *}$ & $(1.86)^{*}$ \\
R-Squared & 8.82 & 8.85 & 5.45 \\
Adj R-Squared & 0.56 & 0.67 & 0.82 \\
\hline
\end{tabular}

Note. $* * * \mathrm{p}<0.01, * * \mathrm{p}<0.05, * \mathrm{p}<0.1$, Values in parenthesis are $\mathrm{t}$-values. 
Table A2. Impact of political regimes and bank specific parameters on ROA

\begin{tabular}{|c|c|c|c|}
\hline Variables & Model 1: Overall & Model 2: $\mathrm{D}_{\text {Rule }}=1$ & Model 3: $\mathrm{D}_{\text {Rule }}=0$ \\
\hline \multirow[t]{2}{*}{ Growth Assets } & 0.008 & 0.007 & 0.007 \\
\hline & $(1.71)^{*}$ & -0.67 & -1.08 \\
\hline \multirow[t]{2}{*}{ Liquidity } & -0.004 & -0.009 & -0.006 \\
\hline & -1.13 & -1.51 & -1.18 \\
\hline \multirow[t]{2}{*}{ Capital Adequacy } & -0.074 & -0.24 & -0.032 \\
\hline & $(2.21)^{* *}$ & $(2.69)^{* * *}$ & -0.72 \\
\hline \multirow[t]{2}{*}{ Management Quality } & 0.013 & 0.55 & 0.011 \\
\hline & $(6.30)^{* * *}$ & $(3.79)^{* * *}$ & $(4.69)^{* * *}$ \\
\hline \multirow[t]{2}{*}{ Growth M2 } & -0.008 & -0.004 & -0.005 \\
\hline & -1.2 & -0.42 & -0.39 \\
\hline \multirow[t]{2}{*}{ Growth GDP } & 0 & 0.001 & 0 \\
\hline & -0.41 & -0.91 & -1.15 \\
\hline \multirow[t]{2}{*}{ Growth Branch } & 0.009 & 0.008 & 0.007 \\
\hline & $(2.98)^{* * *}$ & -1.08 & $(1.85)^{*}$ \\
\hline \multirow[t]{2}{*}{ Constant } & 0.011 & 0.02 & 0.01 \\
\hline & $(4.02)^{* * *}$ & $(3.98)^{* * *}$ & $(2.65)^{* * *}$ \\
\hline F-Statistics & 8.82 & 3.55 & 9.94 \\
\hline R-Squared & 0.56 & 0.61 & 0.74 \\
\hline Adj R-Squared & 0.5 & 0.44 & 0.67 \\
\hline
\end{tabular}

Note. $* * * \mathrm{p}<0.01, * * \mathrm{p}<0.05, * \mathrm{p}<0.1$, Values in parenthesis are $\mathrm{t}$-values.

The paper has been organized as following. After developing literature review on the subject in Section 2, discussion on data, its sources and structure have been detailed in Section 3. Methodology has been presented in Section 4 which is followed by discussion on empirical findings in Section 5. The last section concludes the paper.

\section{Copyrights}

Copyright for this article is retained by the author(s), with first publication rights granted to the journal.

This is an open-access article distributed under the terms and conditions of the Creative Commons Attribution license (http://creativecommons.org/licenses/by/3.0/). 